University of Wollongong

Research Online

Faculty of Arts - Papers (Archive)

Faculty of Arts, Social Sciences \& Humanities

July 2006

\title{
Regulation of hESC Research in Australia: Promises and Pitfalls for Deliberative Democratic Approaches
}

Susan M. Dodds

University of Wollongong, sdodds@uow.edu.au

R. A. Ankeny

University of Sydney

Follow this and additional works at: https://ro.uow.edu.au/artspapers

Part of the Arts and Humanities Commons, and the Social and Behavioral Sciences Commons

\section{Recommended Citation}

Dodds, Susan M. and Ankeny, R. A., Regulation of hESC Research in Australia: Promises and Pitfalls for Deliberative Democratic Approaches 2006.

https://ro.uow.edu.au/artspapers/105

Research Online is the open access institutional repository for the University of Wollongong. For further information contact the UOW Library: research-pubs@uow.edu.au 


\title{
Regulation of hESC Research in Australia: Promises and
}

\section{Pitfalls for Deliberative Democratic Approaches}

\author{
Susan Dodds ${ }^{1}$ and Rachel A. Ankeny ${ }^{2}$ \\ ${ }^{1}$ Associate Professor in Philosophy \\ School of English Literatures \\ Philosophy and Languages \\ University of Wollongong \\ Wollongong, NSW 2522 Australia \\ email: sdodds@uow.edu.au \\ ${ }^{2}$ Senior Lecturer \\ Unit for History and Philosophy of Science \\ University of Sydney, NSW 2006 Australia \\ email: rankeny@science.usyd.edu.au
}

Word count (excluding abstract and references): 7517 


\section{Author declaration}

This article is based on independent work supported by an Australian Research Council

Discovery Grant Big Picture Bioethics: Policy-Making and Liberal Democracy.

No ethical approval was required or sought for this research. 
Abstract (word count: 178)

This paper considers the legislative debates in Australia that led to the passage of the Research Involving Human Embryos Act (Cth 2002) and the Prohibition of Human Cloning Act (Cth 2002). In the first part of the paper, we discuss the debate surrounding the legislation with particular emphasis on the ways in which demands for public consultation, public debate and the education of Australians about the potential ethical and scientific impact of human embryonic stem cells (hESC) research were deployed, and the explicit and implicit framing of the scope of public consultation. We then ask whether, given the calls for public consultations, debate and understanding, current work in democratic theory could be helpful in analyzing the process of policy-making in these areas. In particular, we canvass the literature relating to aggregative and deliberative models of democracy for processes that support the legitimacy of policy. We identify features of the debate that reflect the appeal of deliberative approaches as well as some of the possible hurdles or limitations to developing deliberative democratic approaches to policy in ethically contentious areas.

\section{Keywords}

\section{Embryonic Stem Cell Transplantation}

\section{Bioethics}

Embryo Research

\section{Public Policy}




\section{Introduction}

This article offers a brief historical review of the processes that led to the enactment of Australian Commonwealth (federal) legislation on human embryo experimentation and cloning.(see also 1,2) In light of those aspects of the policy-making process that appealed to public consultation, identification of community standards, and the need for the legislation to be in keeping with the views of the Australian public, we consider the challenges of developing public policy in these ethically contentious areas by drawing on current theoretical work on deliberative democracy.

Prior to 2002, research on human embryos was not regulated directly by federal law. The National Health and Medical Research Council (NHMRC) had developed a series of guidelines that were regularly reviewed and revised concerning embryo research, and several Australian states had legislation regulating both embryo research and assisted reproductive technology (ART). State-based legislation varied considerably, ranging from no legal regulation (relying entirely on the NHMRC guidelines and the judgment of individual research ethics committees in some states such as New South Wales), to quite comprehensive legislation (for instance in Victoria, which arguably as a result was the fastest to be outstripped by technological developments).

In 2000, Alan Trounson, a pioneer in IVF research at the Monash Institute for Reproduction and Development Centre in Melbourne, Victoria, announced successful experiments to develop stem cell lines using human embryonic stem cells (hESC) derived from embryos sourced in Singapore, making his research group among the first in the world to successfully grow hESC. Announcements of successful development of stem cell lines from various research centers around the world and rumors of efforts to engage 
in human cloning led to widespread concern to ensure greater regulatory control over activities that were said to be 'unacceptable' to Australians and their community standards.(see e.g. 3: §11.50-11.56)

At the same time, the state and Commonwealth governments, building on the early research successes in Australia, actively sought investment from the biotechnology industry. The Commonwealth government funded a National Centre for Advanced Cell Engineering in 2002, which was later renamed the Australian Stem Cell Centre, to bring together research teams from the Monash Institute of Reproduction and Development, Monash University, and Adelaide University, as well as the biotechnology companies BresaGen and ES Cell International. In the legislative realm, a series of Senate hearings and an inquiry into human cloning and stem cell research occurred in 2001-2 and eventually resulted in the Research Involving Embryos Act (Cth 2002) and the Prohibition of Human Cloning Act (Cth 2002). More recently, a legislative review of the Australian Research Involving Embryos Act (Cth 2002) and the Prohibition of Human Cloning Act (Cth 2002) has commenced, which is likely to have implications for hESC research.(4)

As most of the publicly accessible debate has occurred in the Australian federal parliament, we focus on legislative processes, including submissions made in the context of various parliamentary reviews, and on popular media coverage of legislative processes. We argue that, at least symbolically, the calls in those processes for ongoing public dialogue, for public education and consultation, and for open discussion about the value of the science and the ethical issues involved in embryo and cloning research express concerns that policy-making in this ethically contentious area should be 
responsive to the attitudes of Australians and should reflect a process of deliberation rather than unreflective preference expression. In fact, as we demonstrate below, there is little evidence that those involved in the legislative process genuinely sought broader public involvement and engagement with the issues raised by the science or the legislation. However, we believe that it is worth asking whether and how developments in democratic theory can usefully guide policy-development processes concerning issues like hESC research and human cloning. We examine the possible application of deliberative models of democracy to policy development in areas such as hESC research and therapeutic cloning and identify some of the possible limitations to such approaches and hurdles they may face.

\section{Part I: The Legislative History}

Australia is composed of six states-New South Wales, Victoria, Queensland, South Australia, Western Australia, and Tasmania—-that are self-governing within the constitutional limits of the federal structure, and two territories - the Northern Territory and the Australian Capital Territory - that have self-governing, regional governments, but that do not have the constitutional status of statehood. The Commonwealth (federal) government has a limited range of legislative responsibilities, which includes power to legislate regarding corporations, commerce, trade, and interstate trade. Both state and federal legislatures can make law regarding criminal offences. The Commonwealth provides the bulk of funding for universities, resources for health care, and public funding for research. The states have direct responsibility for many areas of law and policy, including health law, provision of health services (hospitals), and education. 
Legislation associated with assisted reproductive technology (ART) and embryo experimentation is, constitutionally, a matter for state governance. In proposing the legislation concerning embryo research and cloning, the Commonwealth government chose to make use of its corporations power within the Constitution (Section $51(\mathrm{xx})$ ) to impose consistent law across the country that would provide a framework for future state legislation and override current state legislation that was inconsistent with the Commonwealth law.

Some of the earliest proposed federal legislation related to hESC and embryo research was the Commonwealth Human Embryo Experimentation Bill, introduced in 1985 by Senator Brian Harradine. This bill caused the formation of a Senate Select Committee chaired by Senator Michael Tate.(5) The resulting Tate Report concluded that the bill not be further considered, and instead recommended regulation at the Commonwealth level with cooperation from the states and territories, as well as establishment of a national body to issue research protocols and licenses for embryo experimentation; the bill was never passed by Parliament, and the guidelines recommended Commonwealth regulatory mechanisms of the Tate Committee were never pursued.

Some of the first Australian legislation relating to stem cell research had its roots in earlier state legislation in Victoria $(1984,1995)$, South Australia (1988), and Western Australia (1991), all of which banned destructive research on embryos. This legislation also provided guidelines for storage of embryos for ART and their destruction after a set period (which differed from state to state), as well as a ban on human cloning (although cloning was defined differently in each state). The original Victorian legislation had a 
strict regulatory system that included criminal penalties, which was replaced in the later act by a licensure system for ART clinics and providers. Research that destroys or diminishes the potential for an embryo to be re-implanted was prohibited, which effectively prohibited hESC research. Both the South Australian and Western Australian legislation also included licensure systems and codes of practice for ART providers, but were slightly more permissive with regard to the research activities allowed.

In most other states, committees were convened to examine ART practices. In addition, in New South Wales, the Law Reform Commission issued a set of detailed reports, none of which resulted in legislation.(1) Some states, such as New South Wales, also had additional, specific guidelines requiring ethics committee oversight. In the states and territories without legislation, researchers were primarily bound by the NHMRC's Ethical Guidelines on Assisted Reproductive Technology (1996) (6) and the National Statement on Ethical Conduct in Research Involving Humans (1999),(7) which provided a form of quasi-regulation.(see 8)

The NHMRC is the national body in Australia charged with publicly funding health and medical research and provision of advice and guidelines in health and medicine for public clinical and research settings. As such, it is the main source of formal ethical guidelines for publicly-funded health and medical research, a function administrated through the Australian Health Ethics Committee (AHEC); health advice and clinical guidelines are provided through the Health Advisory Committee. On the issue of embryos, the NHMRC Guidelines in effect prior to 2002 focused on ART services (these providers often also conduct research), and only in this context did the Guidelines address issues of embryo experimentation and (implicitly) human cloning; 
under the Guidelines, sanctions for infringement are not legal but relate to loss of research funding or more informal penalty mechanisms. The Guidelines claimed that there are widely divergent views among Australians with regard to the moral status of the embryo, and hence embryo research, and clearly limited work with human embryos to 'therapeutic procedures which leave the embryo, or embryos, with an expectation of implantation and development'.(6: 10) Even this type of therapeutic research required approval by a human research ethics committee.(cf.9)

The Guidelines also prohibited the production of embryos for purposes other than use in ART, as well as experimentation aimed at the 'development of human embryonal stem cell lines with the aim of producing a clone of individuals'.(6: 15) Finally, the Fertility Society of Australia administers an accreditation committee for ART clinics, which requires compliance with a code of practice that also makes the NHMRC guidelines binding for private clinics; this puts in place a form of self-regulation, though some critics have argued that the system is not adequately independent and that formal legislation would be preferable.(8)

Following news about the cloning of Dolly the sheep, the Commonwealth government, through the Minister of Health and Aged Care, requested more detailed advice on cloning from AHEC, including recommendations for a regulatory model that could articulate with international regulations and guidelines. In response, AHEC specifically recommended that all states and territories introduce legislation to regulate and limit research on human embryos based on the NHMRC Guidelines. In addition, AHEC explicitly recommended that 'informed community discussion' on the potential 
risks and benefits of cloning techniques should be fostered by the Health Minister.(10: 43)

In August of 1999, following continuing popular media coverage of further developments in cloning and hESC research, the Commonwealth Health Minister Dr Michael Wooldridge requested a review of the AHEC report by the Federal Parliament's House of Representatives Standing Committee on Legal and Constitutional Affairs. Two years later, the Andrews Report (named after committee chair Mr Kevin Andrews, MP) was released. In preparing this report, the Committee not only reviewed the existing AHEC Report, but also initiated a public consultation process. The Committee invited submissions from the general public through a website established for the Committee as well as publicity in major newspaper outlets; it also solicited submissions from various governmental agencies, religious representatives, medical and scientific organizations, community representatives likely to have interests in the topic including disease support groups, legal scholars, and bioethicists. The Committee held two public fora early in 2000, at which various spokespersons from religious, bioethical and scientific perspectives were asked to make presentations; attendees could ask questions or make statements following these presentations.(3)

The Andrews Report recommended the establishment of federal legislation for the regulation of both publicly- and privately-funded research on human cloning and stem cells, writing that 'the questions raised by human cloning and research involving the use of embryos are complex social and ethical questions and should not be left to individual ethics committees to decide. Nor should the answer to such fundamental questions depend on geography or source of funding'.(3: xxvi) Commonwealth legislation in this 
area would override existing piecemeal state legislation and also be separate from regulations governing ART. The Report proposed a three-year moratorium on the use of somatic cell nuclear transfer (SCNT) for creation of human embryos and on human reproductive cloning. It proposed that any supernumerary ('surplus') embryos from ART clinics could be used for research that damaged or destroyed the embryos, so long as these projects had the consent of the couple whose tissues were used in the creation of the embryos, had been approved by ethics committees, and had been issued a 'license'; these rules would apply equally to private and public researchers working in Australia.

While the Andrews Committee's deliberations were ongoing, the Council of Australian Governments (COAG) - an organization that fosters discussion between state, territory, and Commonwealth heads of government in an effort to promote consistent legislation — was also debating the regulation of cloning and related technologies. In mid2000, the Australian health ministers agreed to develop 'a national framework to prevent the exploitation of human cloning', and in 2001, COAG began to negotiate nationally consistent legislation to prohibit human cloning.(11) At a meeting in April of 2002, the members of COAG agreed to ban human cloning and to foster a regulation scheme to govern research involving the destruction of existing excess ART embryos that would be nationally consistent. This latter decision was part of a trade-off designed to balance community concerns with the desire 'to enable Australia to remain at the forefront of research which may lead to medical breakthroughs in the treatment of disease'.(12) The premiers of New South Wales, Victoria, and Queensland — the states with the largest research presence in this field - had threatened to allow stem cell research even if the Commonwealth Government sought to ban it. As a compromise, it was agreed that only 
embryos created prior to the COAG meeting held on April 5, 2002, could be used for research. This restriction, set to expire in three years, was introduced to prevent the deliberate creation of embryos intended only for research purposes during that moratorium. The states also agreed to develop state legislation to complement the federal legislation. To date this legislative process has not yet been completed and some of the states with ART legislation have not amended their legislation to make it consistent with the Commonwealth Acts, which, by constitutional authority, override the State Acts where there are inconsistencies.

In June 2002, when the House of Representatives of the Commonwealth Parliament began to consider the Research Involving Embryos and Prohibition of Human Cloning Bill, a considerable amount of debate had already occurred and the COAG guidelines were already in place. The proposed bill prohibited human cloning, as had already been agreed to by the states via COAG, and only allowed experimentation on supernumerary embryos with oversight, again in line with the COAG decisions.

Prime Minister John Howard quickly announced that a 'conscience vote' would be allowed on the bill, an extremely unusual provision that allows voting across party lines and in line with ministers' personal values and moral beliefs. For some this practice is considered to run contrary to representative democracy. Others, however, argue that this is no less consistent with representative democracy than voting along party lines when the matters being voted on are not related to policies aired during the election process. The phrasing of the original bill did not allow a vote in opposition to both cloning and all forms of embryo experimentation, as it explicitly allowed some forms of embryo experimentation. For this reason, the bill was split by the House of 
Representatives in late August of 2002 into the Prohibition of Human Cloning Bill and the Research Involving Human Embryos Bill. Both bills were passed by the House of Representatives. When the two bills were sent to the Senate, the Senate Community Affairs Legislation Committee (chaired by Senator Sue Knowles) established a Selection of Bills Committee of Inquiry that reviewed both bills and delivered a report suggesting considerable disagreement: from a six-member committee came a report containing five distinct positions.(13) Nonetheless, the Senate unanimously passed the Prohibition of Human Cloning Bill in mid-November and the Research Involving Human Embryos Bill was passed by a slim Senate majority in early December. Both bills received Royal Assent and became law in mid-December 2002.

Of particular interest are the licensing provisions in the second Act, administered via the NHMRC by a committee convened to oversee a licensing system allowing use of 'excess' ART embryos up to 14 days of development for research in accordance with the Act. The committee consists of members from a variety of scientific and medical fields, including ART research/practice and stem cell research, as well as regulation, law, bioethics, and consumer perspectives. When granting licenses, the committee is charged to consider the number of excess embryos to be used, the likelihood of significant advances in knowledge or therapies from the research, and alternatives to destructive research, including combining research projects to reduce the overall number of embryos destroyed. The committee is publicly accountable and also has to make periodic reports on its licensing activities. As of April, 2006, nine license applications had been granted by the committee, authorizing the use of 'up to 1740 excess embryos'.(4: 19) 


\section{Democracy and Public Consultation}

In arguments concerning ethically contentious areas of policy development, particularly in cases where scientific knowledge, theories, and techniques are rapidly changing, it is typically assumed that policy-makers should assess and track public attitudes toward the relevant scientific developments. This is due, in part, to the state's role as the 'guardian of the public interest', (14: xxxii) and also to the idea within liberal theory that the legitimacy of public policies depends, in principle, on the ability of the policy-maker to justify those policies to any reasonable member of the society.(15: 44) In the case of the development of the Australian human embryo experimentation and cloning legislation, these assumptions are evident in a number of the Parliamentary reports, including the Andrews Report, various contributions to the Knowles Report, the AHEC submission, and statements by state and federal representatives following the passage of the Act. For instance, the Andrews Report clearly states its concern about the necessity of public consultation in the development of policy concerning human cloning and embryo research:

These are not matters to be decided behind closed doors by scientists or lawyers, however expert and sincere, without widespread community consultation. Nor are they matters that can be resolved by doing nothing. As a society we are confronted with profound issues that require ongoing attention and discussion.(3: xiii)

The Report also appears to hold the view that debate about the significance of scientific advances should be encouraged within the scientific community and should inform regulation: 'So that regulation in this area is appropriate to these benefits and risks [of 
developments in treatment of human diseases], the debate and consultation over the issues arising from the scientific advances in science should be as informed as possible'.(3: 3$)$

In its conclusions, the Andrews Report indicates that AHEC should be charged with responsibility for 'developing and implementing a strategy to consult and involve the public in consideration of the issues arising from this research and encourage debate on the potential and implications of the research'. ${ }^{1}(3: 228)$. Similarly, in submissions to the Andrews Report and in the subsequent debate that led to the passage of the federal legislation, various politicians, ethicists, and legal commentators claimed that there was need for continuing public debate on the social and ethical consequences of hESC research and the potential for therapeutic cloning.(13)

For example, Senators Stott Despoja, Lucas and Webber argued for 'better mechanisms to educate and involve the public in bioethical issues. We need to ensure that the public has access to information, that they are educated about the issues in language they understand, and that they feel able to make their voices heard on the issues'.(13: 170) They recommended a process similar to the U.S. Presidential Commission on Bioethics, which they viewed as constructed to articulate and present 'a variety of views rather than reaching a single consensus opinion. Such a process, properly constituted, could help facilitate a greater understanding of bioethical issues here in Australia'.(13: 170-1) Senators Barnett, Heffernan, Hutchins, and others, citing the submission by the GenEthics Network (16) objecting to NHMRC review, were not convinced that a subcommittee of the NHMRC was the most appropriate body to review the legislation, 
because it would not provide for proper representation of public concerns about the legislation. They argued:

...review by a joint house parliamentary committee, comprising representative numbers of each party [would be] more appropriate. There are serious ethical issues that this review needs to take into account, and not only are members of parliament appropriate representatives of community concerns, but furthermore, it is appropriate that legislators have a role in the review of contentious legislation such as this.(13: 134-5)

\section{Demands for Public Debate and the Implicit Framing of Debates}

Despite these various statements apparently seeking to open up public discussion about the issues raised by $\mathrm{hESC}$ and cloning, there are many reasons to question whether all of those who made such calls genuinely sought open public debate about the legislation. One notable feature of such calls in relation to hESC research was their emphasis on issues around the scientific, social, and ethical potential of the research, where this was understood as largely separable from the economic and financial potential of the research. Although politicians from various perspectives raised questions about the economic impact of hESC research and cloning, the constitutionality of federal regulation, states' interests in attracting the biotechnology industry into their areas, and the risk that "cutting edge' scientists currently employed by Australian research institutions might leave the country to pursue their research elsewhere, these were not among the issues suggested for inclusion in the public debate. The mandate for the public 
debate was tightly circumscribed, focusing on a narrow range of ethical issues, without any clear argument to support such a limited focus (see $3,12,13)$.

Further, despite strong calls for public education, consultation, and debate about embryo research, and the press coverage of the debate, there has not yet been any further inquiry into hESC research since the passage of the legislation. This is particularly surprising given a number of factors. First, the COAG agreement to impose a moratorium on making surplus IVF embryos available for research for three years from April 5, 2002 created a space and a deadline for public debate about the use of such embryos for research, and yet no state or federal body initiated a public consultation process before the moratorium was lifted on April 5, 2005. Second, the legislation that was passed contained an unusually brief time period before it would be reviewed: a review committee was to be established by the NHMRC and report by the end of $2005 .^{2}$ Again, it might have been thought that this short review time was intended to ensure that Australians would have the opportunity to reflect on and respond to the legislation and developing science before the implications of the legislation became entrenched over time, so as to ensure that the legislation tracked the changing attitudes to the evolving scientific situation. However, no formal consultative process has been established or proposed in the period since the enactment of the legislation. In its Issues Paper, the Legislative Review Committee (LRC) states It is not the purpose of reviews to revisit the underpinning community debate and rationale for the two Acts. Rather the purpose is to review the Acts in the light of any changes in scientific or community standards since 
2002, and any indications that the provisions are no longer appropriate and/or practical in their application.(4: 3)

Given the timeframe and structure of the review, it was unlikely that the LRC could truly engage with community standards or values: no open public fora occurred as part of the review, with sessions primarily being facilitated discussions by invitation or expert testimony. The main means for 'members of the public' to express their views was through written submissions; although a relatively high number of submissions were received, many were standard text seemingly provided by various religious organisations.

\section{Part II: Aggregative and Deliberative Models of Democracy}

The processes leading to the passage of the Prohibition of Human Cloning and Research Involving Human Embryos Acts in 2002 do not offer a model of participatory democratic public policy development, despite the many references to a need for public consultation, engagement, and deliberation. There are probably many reasons for this beyond those identified above, including lack of public interest in the issues, economic interests, and party political issues. Nonetheless, it is worthwhile to investigate the potential and the pitfalls of democratic approaches to legitimate policy-making in ethically contentious areas against the backdrop of these recent processes.

Within democratic theory, there are competing ideals of democratic legitimacy: some emphasize that democracy seeks to treat the interests and values of citizens equally, and some emphasize that democracy seeks a politics in which citizens participate in 
reasoning about what policies or institutions ought to be adopted $(17,18)$. These two ideals correspond to aggregative and deliberative models of democracy.

The demand for democratic equality (evidenced in plebiscites or referenda) and representative democracy (where elected representatives mirror the values of the majority who elected them) does not require that the interests implicit in the policies selected through the democratic process reflect the enlightened or considered judgment of the people or demos. Rather, legitimacy comes from the fact that policies reflect the preferences expressed by the majority, however constituted. As Jane Mansbridge describes the process:

Voters pursue their individual interest by making demands on the political system in proportion to the intensity of their feelings. Politicians, also pursuing their own interests, adopt policies that buy them votes, thus ensuring accountability. In order to stay in office, politicians act like entrepreneurs and brokers, looking for formulas that satisfy as many, and alienate as few, interests as possible. From the interchange between selfinterested voters and self-interested brokers emerge decisions that come as close as possible to a balanced aggregation of individual interests.(19: 17) Iris Marion Young describes the approach where voters' interests are uncritically collected in policy formation as an 'aggregative model' of democracy.(20) On this model, legitimacy comes from the reflection or mirroring of interests through accountable legislative processes. The accountability of elected representatives to their constituents through regular elections forces legislators to attend to the interests and preferences of the electorate. The more closely legislators reflect the values of the majority of their 
constituents, the greater the legitimacy of the policies enacted. Politics is not intended to reshape interests, but instead to broker arrangements such that the different arrays of preferences of the majority are reflected in policy.

This emphasis on democratic equality or the aggregative model has been criticized on the following fronts: that it allows those with greater wealth or power to influence unduly how the competing interests are reflected in policy; that voting is a poor process for ranking priorities; that it provides insufficient protection against 'the tyranny of the majority'; that it silences minority interests; that it cannot address issues of uncertainty; and that it frames politics as adversarial, rather than as a normative practice of reciprocal obligation of justification.(19, 21-26) Many critics of aggregative models advocate a 'deliberative turn' towards a politics in which legitimacy is found in critical reasoning processes of deliberation and preference-formation by citizens reflecting on policies and institutions, rather than merely voting on them. Jürgen Habermas describes this model as a return to the 'original meaning of democracy as in terms of the institutionalization of a public use of reason jointly exercised by autonomous citizens'.(27: 23)

A deliberative approach to democracy emphasizes the legitimation of policy that comes from the transformation of interests through processes of ...collective decision making by all those who will be affected by the decision or their representatives: this is the democratic part. Also...it includes decision making by means of arguments offered by and to participants who are committed to the values of rationality and impartiality: this is the deliberative part.(28: 8) 
For Habermas, it is the 'procedures and communicative presuppositions of democratic opinion- and will-formation' that ground rationalization and justification of political decision. However, such exercises of public democratic processes should not be seen as directly determining policy; they can only 'point the use of administrative power in specific directions'.(27: 28-9, see also Dodds S, Thomson C. Bioethics and democracy: the competing roles of national bioethics organizations. Bioethics. Forthcoming 2006.) Recent work extends deliberative approaches by incorporating critical assessment of established power structures that may shape and limit deliberation and recognizing the significance of the historical absence or exclusion of oppressed groups from public reasoning fora. $(20,25)$

In the demand for public, scientific, and expert debate about the ethical issues surrounding hESC research in Australia, there is evidence of appeals both to aggregative legitimacy and to discursive deliberation (even if many of these calls were more symbolic than real). The call by Senator Heffernan and his colleagues for a parliamentary committee to review the legislation, as 'members of parliament [are] appropriate representatives of community concerns',(13: 135) can be understood as based on the aggregative appeal to political legitimacy in the negotiation of citizens' actual preferences, rather than their transformation through deliberation. In contrast, the calls for a forum for public debate on the issues raised by embryo research, human cloning, and the proposed legislation, and particularly the claim by Senator Stott Despoja and her colleagues that there is a need for 'better mechanisms to educate and involve the public in bioethical issues',(13: 170) echo the advocates of deliberative democracy in their suggestion that legitimacy is grounded in processes of public reasoning. Given the 
limitations of aggregative models detailed above, we turn to examining the possibilities and limitations of deliberative models of democracy for democratically legitimate policymaking processes.

\section{The Challenge of Deliberation}

Is a deliberative approach to democratic legitimacy an appropriate ideal for democratic decision-making in ethically-contentious areas such as hESC research, embryo experimentation more generally, or therapeutic cloning? In this section, we identify some of the hurdles that a deliberative approach would have to surmount, and some of the 'pathologies of deliberation' that could beset debate concerning embryo research. We consider various preconditions for effective deliberation and offer two examples of policy-making processes in similar areas that have been used in Australia and Canada and that appear to fulfill these basic preconditions to a greater or lesser extent. We argue that these examples could be followed in public deliberation regarding hESC regulation.

The first hurdle to processes of deliberative democracy is the willingness of deliberators to change their mind as the result of deliberation and the attitude of deliberators towards each other's opinions. As John Dryzek writes:

One defining feature of deliberative democracy is that individuals participating in democratic processes are amenable to changing their minds and their preferences as a result of the reflection induced by deliberation.(25: 31$)$

The requirement that individuals be prepared to 'play the game' of deliberation - to participate in the exercise of public reasoning with an open mind to the views of other 
deliberators-goes to the heart of the democratic appeal of deliberative approaches. Citizens participating in processes of deliberation can be thought of as motivated by concern for 'the common good' or at least minimal respect for the distinct views of their fellow citizens. Amy Gutmann and Dennis Thompson argue that deliberative approaches appeal to a notion of justice, namely that of reciprocity, and that reciprocity entails a level of respect for fellow citizens and hence recognition of a need to justify one's views to them:

Reciprocity holds that citizens owe one another justifications for mutually binding laws and public policies that they collectively enact. The aim of a theory that takes reciprocity seriously is to help people to seek political agreement on the basis of principles that can be justified to others who share the aim of reaching such an agreement.(18: 33)

If we consider this point in relation to the case of research involving human embryos and human cloning in Australia, there may well have been widespread agreement that there was a need for a clear policy. The chief impetus for national legislation was the uncertainty and inconsistency associated with the existing system of distinct legislation in three states and self-regulation in the other jurisdictions.(3:211-2) However, it is less clear that the potential participants in deliberation about the appropriate mode of regulation in this area were open to changing their minds in light of deliberative processes. While many participants in the debate shared an 'overlapping consensus'(29) on the ethical, social, and economic issues associated with hESC research, there were also participants who held highly polarized views about the moral status of embryos, the value of scientific progress, the potential for commerce in 
biotechnology, and the potential for research in this area to realize health equity. Unless there is a shared commitment to the process of policy deliberations, the ethical divide between those who value human embryos as having the same or very similar moral status to adult humans, and those who view such 'surplus' embryos as valuable resources for research and the development of novel pharmaceutical products, leaves little room for reflective preference transformation.

F. N. Gambetta writes about the challenge of deliberation in cultures that value 'winning arguments' over the presentation of arguments in order to elucidate positions and persuade others.(30) He argues that in countries where a culture predominates by dismissing rather than engaging with one's opponent, there will be a need for institutions to protect deliberative processes by limiting adversarial approaches and encouraging tentative deliberations that acknowledge the partiality of deliberators' knowledge and authority. Gambetta argues, however, that it is easier to develop these institutions in the case of deliberation about beliefs, rather than about values, including the value of adversarial debate. If Gambetta is right, then reciprocal respect for significantly differing knowledge claims (e.g., concerning the science of hESC) is more readily developed than reciprocal respect for widely differing values (e.g., concerning the ethical status of supernumerary ART embryos). This conclusion suggests that debate among those with fundamentally opposed value systems is not certain to yield deliberative outcomes that meet the Habermasian standard for legitimacy, because the parties do not wish to respect a duty of reciprocal regard for the values of those with whom they are deliberating.

Cass Sunstein reinforces Dryzek's argument and gives further reasons to be skeptical about the potential for deliberation on contentious issues in contexts where 
members of deliberating groups share values related to an identity. He describes the 'law of group polarization' as follows:

Group polarization means that members of a deliberating group predictably move toward a more extreme point in the direction indicated by the members' predeliberation tendencies.... Notably, groups consisting of individuals with extremist tendencies are more likely to shift, and likely to shift more...; the same is true for groups with some kind of salient shared identity.(31: 81)

The effect of group polarization is that groups make more extreme decisions than the average individual member of the group would make on her own.(31: 82) Polarization occurs most frequently when groups with some shared values (e.g., political parties or interest groups) consider policies without outside influence, or without having to reflect on or seriously respond to alternative arguments. Within such groups, there is a high degree of consensus and shared opposition to views held by other groups. The law of group polarization suggests in the absence of deliberators with diverse views and identifications, the deliberation will tend towards an extreme position. Sunstein argues that effective deliberation requires a degree of disagreement: in other words, the deliberative group's openness to alternative views is a requirement for legitimate deliberation and the process of deliberation about public policy needs to be open, rather than occurring in separate, polarizing enclaves. If deliberation about a policy affecting a diversity of people occurs by a process where deliberators are divided into separate groups the members of which are relatively homogenous, then, on Sunstein's view, the outcome of those separate deliberations will be increased polarization between the 
deliberative groups rather than the emergence of views that can claim democratic legitimacy.

A further challenge to deliberation in areas of rapid scientific development is that the citizenry who might participate in deliberative discussion often lack (or feel that they lack) the knowledge and information required to evaluate the science or policies under consideration. Alan Irwin notes the need for development of a public understanding of science, and hence for experts to engage in open debate about the value and risks of relevant scientific developments so that citizen-deliberators are in a position to weigh the merits of the scientific arguments for themselves.(32) As Dryzek puts it, an effective citizen voice in economic and technological developments requires a citizenry that is appropriately circumspect in its response to the authority of experts:

...distrust of experts does not mean that everyone has to become an expert. Instead, it can mean approaching expert testimony with a sceptical attitude, perhaps questioning the credentials of experts, seeking corroboration for any contentious claim, refusing to believe an expert if his or her research is funded by the offending industry, or if his or her record indicates an axe to grind.(25: 165) It is unlikely that 'experts' in the debates surrounding hESC research in Australia will be considered free from potential bias: the scientists who have the greatest experience of the research are often those, like Trounson, who have been at the forefront of the research and who have the most to gain in terms of research and financial opportunities. The ethical and religious 'experts' who have pronounced on the issues (e.g., in submissions to the Andrews inquiry and the recent LRC) often express views based in their religious or ideological commitments. Therefore, in order to have effective deliberation, the citizens 
who will be affected by the regulations must develop critical skills in evaluating the claims made by experts on all sides. The primary avenue for most citizens to gain information about these developments is the mass media; however such sources primarily provide 'sound-bite' news reports or current affairs programs that seek to reduce complex issues to simplistic adversarial positions.(30: 40) The hESC debate in Australia has been framed in the media as a 'science versus religion' debate that oversimplifies and polarizes the range of plausible positions. Policy-makers who seek to be informed by public deliberative processes will need to identify means for developing public fora within which truly effective deliberation may occur.

\section{Conclusion - Deliberative Optimism}

Our conclusion to this overview of some of the challenges for deliberative democracy is not, ultimately, as pessimistic as it might first seem. We note the significant limitations of aggregative approaches and the political and economic influences that raise questions about the legitimacy of bargain-based preference expression as a means of legitimating policy. We also recognize the challenges facing those who would seek to develop models for open deliberative discussion of policy that could then inform legislators. However, we do not believe that the challenges are insurmountable or should be avoided. Indeed, within Australia there is a precedent for more deliberative policy formulation in relevantly similar areas to hESC research and human cloning, namely the process that framed the report of the Australian Law Reform Commission (ALRC) and AHEC on genetic privacy entitled Essentially Yours: The Protection of Human Genetic Information in Australia.(33) While the process may not be without criticism, it suggests 
a way forward for developing practical approaches to consultation that are directed towards the ideal of legitimacy grounded in processes of public reasoning. $(34,35)$

Unlike the Andrews report, which was based firmly within the political legislative process, the ALRC and AHEC joint inquiry was an independent report to the Attorney General. The terms of reference for the report specifically charged the ALRC and AHEC with determining whether regulation was required (and, if so, in what form), in order to protect privacy of human genetic samples and genetic information, to protect against discriminatory use of genetic samples and information, and 'to reflect the balance of ethical considerations relevant to the collection and uses of human genetic samples and information in Australia'.(33: 13)

In carrying out its work, the ALRC and AHEC were to 'identify and consult with relevant stakeholders, including the Privacy Commissioner and the Human Rights and Equal Opportunity Commission, and ensure widespread public consultation'.(33: 13-14) Regulation of human genetic privacy, in our view, is no less technically complex than regulation of hESC research. Given the potential developments in genomics and social policy surrounding genetics, genetic privacy matters may become as socially divisive as hESC research. Even if debates surrounding human embryo research prove to be more divisive than those about genetic privacy, that is not a reason for avoiding deliberation, given the significance of the process of public reasoning for the legitimacy of the resultant policy. The process that the ALRC and AHEC joint inquiry followed in meeting its aims fulfilled many of the preconditions discussed above and followed closely an iterative deliberative process for bioethical policy-making.(as recommended in Dodds S, Thomson C. Bioethics and democracy: the competing roles of national bioethics 
organizations. Bioethics. Forthcoming 2006.) The Inquiry started its process of public consultation with the release of an Issues Paper, setting out the key issues relevant to development of policy in the area of genetic privacy, from the perspective of legal, ethical, and scientific experts (members of an expert Advisory committee established as part of the Inquiry, and with reference to the position of various relevant international bodies such as UNESCO and HUGO). The Issues Paper was circulated widely in hard and soft copy as the first step in the public consultation process. Nearly a year later, the matters raised in that Issues Paper together with the response to that paper by key stakeholders (and other expert input) were refined into a Discussion Paper that was again widely circulated in hard copy and on the internet to promote public education and debate on the issue of genetic privacy. The ALRC and AHEC joint inquiry process reflected its key aim 'to find a sensible path that meets twin goals: to foster innovations in genetic research and practice that serve humanitarian ends, and to provide sufficient reassurance to the community that such innovations will be subject to proper ethical scrutiny and legal (and other) controls'.(33: 33-34)

The direct community consultation process involved a number of face-to-face meetings and public submissions. There were also 15 open public fora in capital cities and regional centers, at which members of the Inquiry's Working Group presented information about the issues and process of the Inquiry; questions and comments from the people who attended also were recorded, opening up debate among members of the public and experts. Over 200 meetings were held between the ALRC and AHEC team and key stakeholders, including meetings with international bodies. Over 300 written submissions were received, most of which were made available publicly through the 
Inquiry's website. The Inquiry made 144 recommendations to state and federal legislators.(33: 97-102)

Those recommendations reflect a debate that, while focused through the terms of reference set by the Attorney General, was not narrowly restricted to discussion of Australians' ethical attitudes to specific features of the issues at stake. The submissions received and contributions made to the public meetings can be viewed as more genuinely reflecting a process of deliberation within which the participants were seeking to understand, explain, and persuade others with regard to matters relevant to policy development, rather than 'scoring points' in a political bargain for a specific legislative outcome.

While it is possible for these intensive iterative consultation processes to be subverted by well-organized groups reflecting one perspective held in the community, it is certainly the case that any legislation that is developed as a result of this type of process and based on the recommendations of the Inquiry can make a claim to legitimacy based on public deliberation in a way that legislation that has not had the benefit of such a process cannot.

Would the outcome of the legislation concerning human embryo research and cloning in Australia have been different if the process had been more deliberative? We suggest that the answer to this question is yes, because there would have been greater opportunity to assess the views of Australians, and for those views to shape the legislative debate. The outcome may not have been substantively different, however, even if the political influence on the process of deliberation had been minimal. For the deliberative approach, the outcome is not the point; the key is the legitimacy conferred by 
the process on the outcome. If there is a shared public commitment to deliberative preference formation, and if the cultural conditions are set for non-polarizing deliberation and for skeptical reflection on expert contributions, then the Andrews Report, the Research Involving Embryos Act (2002), and the Prohibition of Human Cloning Act (2002) could be starting points for future public debate about the social, ethical, and economic values at stake in the development of hESC research. They cannot be viewed, given their history of closed parliamentary inquiries and public consultation limited in both scope and volume, as evidence of a process of deliberative policy development. That deliberation, and the legitimacy that would be afforded to policy informed by it, has yet to be seen in Australia on the issue of hESC research, but it could be developed using methods similar to the ALRC and AHEC Inquiry process. An opportunity to do so could arise when Parliament receives the report of the LRC and again when the NHMRC Guidelines relating to human embryo research and human cloning are next reviewed. It will be interesting to witness the further processes that result from the recommendations of the LRC, but there is little reason to be optimistic that the immediate legislative process will be characterized by effective deliberation, particularly if it is conducted in the usual manner. 


\section{Acknowledgements}

This work was supported by an Australian Research Council Discovery Grant Big Picture Bioethics: Policy-Making and Liberal Democracy. The paper has benefited from comments and suggestions by the reviewers from this special issue as well as by Françoise Baylis, Fiona Mackenzie, and Kerry Ross. 


\section{References}

1. Chalmers D. Professional self-regulation and guidelines in assisted reproduction. Journal of Law and Medicine. 2002;9:414-428.

2. Hall W. The Australian policy debate about human embryonic stem cell research. Health Law Review. 2004;12:27-33.

3. Andrews K (chair), House of Representatives Standing Committee on Legal and Constitutional Affairs. Human cloning: scientific, ethical and regulatory aspects of human cloning and stem cell research. Canberra: Commonwealth of Australia; 2001.

4. Lockhart JS (chair), Legislation Review Committee. Issues paper: outline of existing legislation and issues for public consultation [Legislation Review of Australia's Prohibition of Human Cloning Act 2002 and Research Involving Human Embryos Act 2002]. Canberra: Biotext, 2005.

5. Tate M (chair), Senate Select Committee on the Human Embryo Experimentation Bill 1985, Parliament of Australia. Human embryo experimentation in Australia. Canberra: Parliament of the Commonwealth of Australia; 1986.

6. National Health and Medical Research Council (NHMRC). Ethical guidelines on assisted reproductive technology. Canberra: Commonwealth of Australia; 1996.

7. NHMRC. National Statement on Ethical Conduct in Research Involving Humans. Canberra: Commonwealth of Australia; 1999.

8. Nicol D, Chalmers D, Gogarty B. Regulating biomedical advances: embryonic stem cell research. Macquarie Law Journal. 2002;2:31-59.

9. Harvey O. Regulating stem-cell research and human cloning in an Australian context: an exercise in protecting the status of the human subject. New Genetics and Society. 2005;24:125-136.

10. Australian Health Ethics Committee (AHEC); National Health and Medical Research Council (NHMRC). Scientific, ethical and regulatory considerations relevant to cloning human beings. Canberra: Commonwealth of Australia; 1998.

11. Council of Australian Governments (COAG). Communique of meeting held on June 8, 2001. [Cited 2006 April 24]. Available from: http://coag.gov.au/meetings/080601/index.htm.

12. COAG. Communique of meeting held on April 5, 2002. [Cited 2006 April 24]. Available from: http://coag.gov.au/meetings/050402/index.htm

13. Knowles $\mathrm{S}$ (chair), The Senate Community Affairs Legislation Committee. Provisions of the Research involving Human Embryos and Prohibition of Human Cloning Bill 2002 [Selection of Bills Committee of Inquiry]. Canberra: Parliament of the Commonwealth of Australia; 2002.

14. Canadian Royal Commission on New Reproductive Technologies (CRCNRT). Proceed with care: final report of the Royal Commission on New Reproductive Technologies. Ottawa: Government of Canada; 1993.

15. Waldron J. Liberal rights: collected papers 1981-1991. New York: Cambridge University Press; 1993.

16. GenEthics Network. Submission to the Senate Committee on the bill to regulate research involving embryos, October 2002. [Cited 2005 May 14]. Available from http://www.geneethics.org/community/modules.php?name=Sections\&op=viewart icle\&artid $=21$. 
17. Fishkin JS. Deliberative democracy. In: Simon RL, editor. The Blackwell guide to social and political philosophy. Oxford: Blackwell Publishers; 2002. p. 221-238.

18. Gutmann A, Thompson D. Deliberative democracy beyond process. In: Fishkin JS, Laslett P, editors. Debating deliberative democracy. Oxford: Blackwell Publishers; 2003. p. 31-53.

19. Mansbridge J. Beyond adversary democracy. New York: Basic Books; 1980.

20. Young IM. Inclusion and democracy. New York: Oxford University Press; 2000.

21. Arrow KJ. Social choice and individual values. $2^{\text {nd }}$ ed. New York: John Wiley \& Sons; 1951.

22. Habermas J. Legitimation crisis. Boston: Beacon Press; 1975.

23. Young IM. Justice and the politics of difference. Princeton: Princeton University Press; 1990.

24. Fishkin JS. The voice of the people: public opinion and democracy. New Haven: Yale University Press; 1995.

25. Dryzek JS. Deliberative democracy and beyond: liberals, critics, contestations. Oxford, New York: Oxford University Press; 2000.

26. Miller D. Deliberative democracy and social choice. In: Fishkin JS, Laslett P, editors. Debating deliberative democracy. Oxford: Blackwell Publishers; 2003. p. 182-199.

27. Habermas J. Three normative models of democracy. In: Benhabib S, editor. Democracy and difference. Princeton: Princeton University Press; 1996. p. 21-30.

28. Elster J. Introduction. In: Elster J, editor. Deliberative democracy. Cambridge: Cambridge University Press; 1998. p. 1-18.

29. Rawls J. A theory of justice. New York: Basic Books; 1971.

30. Gambetta D. 'Claro!': an essay on discursive machismo. In: Elster J, editor. Deliberative democracy. Cambridge: Cambridge University Press; 1998. p. 19-43.

31. Sunstein CR. The law of group polarization. In: Fishkin JS, Laslett P, editors. Debating deliberative democracy. Oxford: Blackwell Publishers; 2003. p. 80-101.

32. Irwin A. Citizen science: a study of people, expertise and sustainable development. New York: Routledge; 1995.

33. Australian Law Reform Commission (ALRC); National Health and Medical Research Council (NHMRC); Australian Health Ethics Committee (AHEC). Essentially yours: the protection of human genetic information in Australia. Sydney: Australian Law Reform Commission; 2003.

34. Bohman J. Survey article: the coming of age of deliberative democracy. The Journal of Political Philosophy. 1998;6:400-425.

35 . Benhabib S. The claims of culture: equality and diversity in the global era. Princeton: Princeton University Press; 2002.

\footnotetext{
${ }^{1}$ It is interesting, in light of this view, that Recommendation 9, which immediately follows this explanation, makes a less explicit claim with regard to public consultation: 'The Committee recommends that the Australian Health Ethics Committee (AHEC) be responsible for monitoring scientific developments in this area, analysing their potential impact and providing advice to Commonwealth, State and Territory governments on these matters' (Andrews, 2001, pp. 228-9). The Recommendation seems designed to leave public consultation and debate out of the process that generates advice to governments.
} 
${ }^{2}$ A six-member Legislation Review Committee (LRC), chaired by John S. Lockhart, was established in mid-2005 and submitted its report to COAG for its 19 December 2005 deadline; the report was also tabled in both Houses of the Australian Parliament and will be debated in 2006 (Lockhart, 2005, p. 4). 